Jurnal DIALOGIKA Manajemen dan Administrasi

Homepage: https://ejurnal.unma.ac.id/index.php/dialogika

Vol. 3 No. 1, Februari 2022, halaman: 41 48

E-ISSN: 2720-9865, P-ISSN: 2716-3563

DOI : https://doi.org/10.31949/dialogika.v3i1.2115

\title{
ANALISIS HUBUNGAN FAKTOR-FAKTOR KUALITAS PELAYANAN DENGAN KINERJA PELAYANAN PUBLIK
}

(Studi pada Sekretaris Daerah Kabupaten Bogor)

\author{
Tiara Yulizar Puteri ${ }^{*}$, Otong Karyono ${ }^{2}$, Kania Agustina ${ }^{3}$ \\ (1)Mahasiswa Pascasarjana Ilmu Administrasi, Universitas Majalengka, Jawa Barat, Indonesia \\ (2)(3)Dosen Pascasarjana Ilmu Administrasi, Universitas Majalengka, Jawa Barat, Indonesia \\ ${ }^{1 *}$ Email penulis koresponden: pps@unma.ac.id
}

Disubmit Desember 2021, diterima Januari 2022, diterbitkan Februari 2022

Submitted December 2021, Accepted January 2022, Published February 2022

\begin{tabular}{|c|c|}
\hline Penulis koresponden & Abstract \\
\hline & $\begin{array}{l}\text { This research aims to analyze the relationship between service quality factors and } \\
\text { service performance carried out in the Bogor Regency Regional Secretary } \\
\text { environment. This research uses quantitative methods with data collection techniques } \\
\text { through research questionnaires distributed to } 164 \text { employees who have the task of } \\
\text { providing services, with the analysis technique used is multiple correlation analysis. } \\
\text { The results of the study prove empirically that the quality factors of service have a } \\
\text { significant relationship with service performance. }\end{array}$ \\
\hline & Keywords: Service Quality; Service Performance; Government. \\
\hline & Abstrak \\
\hline DIALOGIKA & Penelitian ini memiliki tujuan untuk menganalisis hubungan antara faktor-faktor \\
\hline diterbitkan & kualitas pelayanan dengan kinerja pelayanan yang dilaksanakan di lingkungan \\
\hline Program Pascasarjana & Sekretaris Daerah Kabupaten Bogor. Penelitian ini menggunakan metode kuantitatif \\
\hline Administrasi Publik & dengan teknik pengumpulan data melalui angket penelitian yang disebarkan kepada \\
\hline Universitas Majalengka & $\begin{array}{l}164 \text { pegawai yang memiliki tugas memberikan pelayanan, dengan teknik analisis yang } \\
\text { digunakan adalah analisis korelasi berganda. Hasil penelitian membuktikan secara } \\
\text { empiris bahwa faktor-faktor kualitas pelayanan memiliki hubungan yang signifikan } \\
\text { dengan kinerja pelayanan. }\end{array}$ \\
\hline
\end{tabular}

Kata kunci: Kualitas Pelayanan; Kinerja Pelayanan; Pemerintahan.

\section{(i) This work is licensed under a Creative Commons Attribution 4.0 International License}

masyarakat dengan sumber dana yang berasal dari pajak yang diperoleh dari

\section{PENDAHULUAN}

Tuntutan revolusi industry 4.0 membawa dampak terhadap perubahan tata kelola pemerintah menjadi open government. Teknologi, Informasi dan Komputer merupakan media utama dalam membangun transparansi dan membuka ruang partisipasi, sehingga tata kelola pemerintah dalam revolusi industry industry 4.0 lebih mengedepankan tata kelola digital dalam pemerintahan. Pemerintah sebagai organisasi sector publik yang merupakan lembaga yang menjalankan roda pemerintah yang menyediakan pelayanan berupa barang/jasa bagi masyarakat dan ditunjukkan kembali kepada masyarakat. Pemerintah daerah sebagai pihak yang diberikan tugas menjalankan roda pemerintahan, pembangunan, dan pelayanan masyarakat wajib menyampaikan laporan pertanggungjawaban keuangan daerahnya untuk dinilai apakah pemerintah daerah berhasil menjalankan tugasnya dengan baik atau tidak (Halim dan Khusufi,2013).

Organisasi ini bertujuan untuk melayani kebutuhan masyarakat demi kesejahteraan sebagaimana diamanatkan oleh konstitusi sebagai pijakan dalam operasionalnya. Organisasi publik 
berorientasi pada pelayanan kepada masyarakat tidak pada profit/laba/untung. Hal ini mendorong organisasi publik untuk dapat mengelola jasa pelayanan publik secara baik dan bertanggungjawab. Pengukuran kinerja sangat penting untuk menilai akuntabilitas organisasi dan manajer dalam menghasilkan pelayanan publik yang lebih baik. Pengukuran kinerja berguna untuk membantu manajer publik menilai pencapaian suatu strategi melalui alat ukur finansial dan non finansial. Pengukuran kinerja juga berfungsi untuk mengkomunikasikan strategi secara lebih baik, mengidentifikasi kepuasan pelanggan, serta sebagai alat komunikasi antara bawahan dan pimpinan dalam rangka memperbaiki kinerja organisasi. Sistem pengukuran kinerja sektor publik adalah suatu sistem yang bertujuan untuk membantu manajer publik menilai pencapaian suatu strategi melalui alat ukur finansial dan nonfinansial.

Tuntutan baru muncul agar organisasi sektor publik memperhatikan value for money dalam menjalankan aktivitasnya. Value for money merupakan konsep pengelolaan organisasi sektor publik yang mendasarkan pada tiga elemen utama, yaitu ekonomi, efisiensi dan efektivitas (Mardiasmo, 2009: 4). Value for money merupakan suatu tolok ukur dalam anggaran belanja suatu organisasi, baik organisasi yang berorientasi laba maupun organisasi non profit (Kadafi, 2014). Value for money merupakan inti dari pengukuran organisasi publik. Kinerja pemerintah tidak dapat dinilai dari sisi output yang dihasilkan saja, tetapi juga harus mempertimbangkan input, output dan outcome secara bersama-sama.

Untuk mencapai kinerja yang baik bagi pemerintah daerah secara akuntabilitas, tidak lepas dari pelayanan public yang diberikan oleh instansi pemerintah. Keberhasilan pelayanan public merupakan cermin dari keberhasilan kinerja pemerintah dalam memberikan pelayanan. Pelayanan public sendiri merupakan cita-cita reformasi birokrasi yang diatur dalam undang-undang nomor 25 tahun 2009 tentang pelayanan publik. Sesuai dengan Pasal 1 Ayat (1) Undang-Undang Nomor 25 Tahun 2009 Tentang Pelayanan Publik dinyatakan bahwa Pelayanan Publik merupakan kegiatan atau rangkaian dalam rangka pemenuhan kebutuhan pelayanan sesuai dengan peraturan perundang-undangan bagi setiap warga negara dan penduduk atas barang, jasa, dan/atau pelayanan administratif yang disediakan penyelenggara pelayanan publik. Sedangkan menurut Pasolong (2010:199) pelayanan publik adalah melayani keperluan masyarakat yang mempunyai kepentingan pada organisasi tertentu sesuai dengan aturan pokok dan tata cara yang telah ditetapkan. Dengan demikian, pelayanan publik merupakan pemenuhan keinginan dan kebutuhan masyarakat yang diberikan oleh aparatur negara dengan tujuan untuk meningkatkan kesejahteraan masyarakat.

Permasalahan instansi pemerintah dalam pelayanan public adalah masih buruknya kualitas pelayanan public. Buruknya pelayanan publik selama ini menjadi salah satu variabel yang mendorong munculnya krisis kepercayaan masyarakat kepeda pemerintah. Krisis kepercayaan masyarakat teraktualisasi dalam bentuk protes dan demonstrasi yang cenderung tidak sehat menunjukan kefrustasian publik terhadap pemerintahannya. Oleh karena itu, perbaikan kualitas pelayanan, sumberdaya manusia dan kinerja organisasi mutlak diperlukan agar image buruk masyarakat kepada pemerintah dapat diperbaiki, karena dengan perbaikan kualitas pelayanan yang semakin baik, dapat mempengaruhi kepercayaan masyarakat sehingga kepuasan masyarakat terhadap pemerintah dapat dibangun kembali.

Menilai kualitas pelayanan publik bukanlah kegiatan yang sangat mudah khususnya pemberian pelayanan publik yang bersifat jasa maupun administratif, namun terlepas dari persoalan tersebut masalah mengenai kualitas pelayanan publik pada saat ini menjadi pusat perhatian di berbagai Negara demokratis khususnya Indonesia karena pemberian pelayanan publik pada saat ini menjadi tolok ukur suatu Negara dikatakan gagal atau baik, untuk mengukur kualitas pelayanan publik adakalanya peneliti memaparkan penjelasan mengenai pengertian kualitas pelayanan dari berbagai pakar. Menurut Brady dan Conin dijelaskan bahwa "kualitas pelayanan merupakan perbandingan antara kenyataan atas pelayanan yang diterima dengan 
harapan atas pelayanan yang ingin diterima" (Afrial, 2009). Sedangkan ditambahkan oleh Parasuraman, Zeithaml, dan Berry dalam (Samosir, 2005) "kualitas pelayanan adalah perbandingan yang diharapkan konsumen dengan pelayanan yang diterimanya".

Dari pengertian dari berbagai pakar tersebut dapat dipahami bahwa masyarakat dalam memberikan penilaian terhadap kualitas pelayanan berdasarkan perbandingan pengalaman yang pernah dirasakan dengan apa yang diharapkan atas pelayanan tersebut. Seperti yang dijelaskan sebelumnya bahwa didalam suatu organisasi, konsep kualitas pelayanan menjadi ukuran keberhasilan organisasi, keberhasilan organisasi yang dimaksud baik itu pada organisasi bisnis maupun juga pada organisasi yang bertugas untuk menyediakan pelayanan publik.

Dalam penyelenggaraan mengenai pelayanan publik, pemerintah dalam Undang-Undang tentang pelayanan publik Nomor 25 Tahun 2009 dan Keputusan Menteri Pendayagunaan Aparatur Negara Nomor 63/KEP/M.PAN/7/2003 telah merumuskan apa yang menjadi asas, prinsip, dan standar pelayanan publik hal ini bertujuan untuk meningkatkan kualitas pelayanan publik. Namun dari pengamatan peneliti bahwa prinsip dan standar pelayanan publik yang digariskan oleh pemerintah sangat sulit dioperasionalisasikan untuk mengukur kualitas pelayanan publik, karena pada dasarnya dalam penelitian kuantitatif dibutuhkan konsep yang jelas sebagai dasar peneliti untuk melakukan penelitian agar dapat menggambarkan keterukuran yang lebih nyata sesuai dengan situasi dan kondisi di lapangan. Dalam mengukur kualitas pelayanan publik, peneliti menggunakan teori yang dikemukakan oleh parasuraman, et.al. Dalam mengukur sejauh mana kualitas pelayanan publik yang diberikan oleh pemerintah. Dalam mengevaluasi kualitas pelayanan tidak hanya ditentukan oleh pemerintah saja namun juga ditentukan oleh masyarakat, hal ini seperti yang dijelaskan oleh Barata (2003) bahwa berbicara mengenai kualitas pelayanan, ukurannya bukan hanya ditentukan oleh pihak yang melayani saja tapi lebih banyak dilayani, karena merekalah yang menikmati layanan sehingga dapat mengukur kualitas pelayanan beradasarkan harapan-harapan mereka dalam memenuhi kepuasannya.

$$
\text { Kinerja atau disebut juga }
$$

performance dapat berarti prestasi penyelenggaraan sesuatu, Moenir (2000). Kinerja merupakan prosedur yang meliputi: penetapan standar kinerja, penilaian kinerja actual pegawai dalam hubungan dengan standar-standar ini, memberikan umpan balik kepada pegawai dengan tujuan memotivasi orang tersebut untuk menghilangkan kemerosotan kinerja atau terus berkinerja lebih tinggi lagi, Simamora (2001). Untuk mengetahui sejauh mana kinerja dari suatu organisasi pemerintahan, maka dipandang perlu dilakukan suatu kegiatan evaluasi kinerja. Pentingnya evaluasi kinerja dari suatu organisasi pemerintahan oleh Keban (1995:1) dikatakan bahwa: Bagi setiap organisasi, penilaian terhadap kinerja merupakan suatu kegiatan yang sangat penting, penilaian tersebut dapat digunakan sebagai ukuran keberhasilan suatu organisasi dalam kurun waktu tertentu. Penilaian tersebut dapat juga dijadikan input bagi perbaikan atau peningkatan kinerja organisasi selanjutnya. Terdapat dua ukuran utama untuk menilai kinerja organisasi pemerintahan, yaitu ukuran produktivitas dan ukuran pelayanan, Dwiyanto (1995) mengemukakan tiga indikator utama mengukur kinerja organisasi pemerintahan, yaitu: 1) Responsivitas adalah kemampuan organisasi untuk mengenali kebutuhan masyarakat, menyusun agenda dan prioritas pelayanan dan mengembangkan program-program pelayanan masyarakat sesuai kebutuhan dari aspirasi masyarakat. Responsibilitas yaitu menunjuk pada keselarasan antara program dan kegiatan pelayanan dengan kebutuhan dan aspirasi masyarakat untuk mencapai misi dan tujuannya. 3) Akuntabilitas adalah pengukuran sejauhmana para wakil rakyat atau pejabat politisi dan tokoh masyarakat dalam memperjuangkan aspirasi masyarakat.

Kepercayaan adalah suatu kemauan atau keyakinan mitra pertukaran untuk menjalin hubungan jangka panjang untuk menghasilkan kerja yang positif, Yulianto dan Waluyo (2004). Kepercayaan ada ketika sebuah kelompok percaya pada sifat 
terpercaya dan integritas mitra. Kepercayaan adalah ekspektasi yang dipegang oleh individu bahwa ucapan seseorang dapat diandalkan. Kelompok terpercaya perlu memiliki integritas tinggi dan dapat dipercaya, yang diasosiasikan, dengan kualitas yaitu: konsisten, kompeten, jujur, adil, bertanggungjawab, suka membantu dan baik, Yulianto dan Waluyo (2004:350). Kemampuan berkomunikasi yang efektif merupakan instrumen untuk menghasilkan kepercayaan pelanggan. Komunikasi yang efektif akan membantu pelanggan untuk meningkatkan pengetahuan dan pemahaman tentang pentingnya menciptakan kepercayaan pada perusahaan penyedia jasa, karena komunikasi yang sering dan bermutu tinggi akan menghasilkan kepercayaan yang lebih besar, Yulianto dan Waluyo (2004).

Kepuasan masyarakat merupakan faktor utama yang harus diperhatikan oleh penyedia pelayanan publik, karena kepuasan masyarakat akan menentukan keberhasilan pemerintah dalam menyelenggarakan pelayanan publik. Definisi kepuasan masyarakat sering disamaartikan dengan definisi kepuasan pelanggan atau kepuasan konsumen, hal ini hanya dibedakan pada siapa penyedia dan apa motif diberikannya pelayanan tersebut. Penyedia pelayanan di dalam pelayanan publik adalah pegawai instansi pemerintah yang melaksanakan tugas pelayanan publik sesuai dengan peraturan perundang-undangan yang telah diamanatkan dan penerima pelayanan publik adalah orang, masyarakat, lembaga instansi pemerintah dan dunia usaha, yang memperoleh manfaat dari suatu kegiatan penyelenggaraan pelayanan publik. Kepuasan pelayanan berdasarkan Kep./25/M.PAN/2/2004 yaitu hasil pendapat dan penilaian masyarakat terhadap kinerja pelayanan yang diberikan oleh aparatur penyelenggara pelayanan publik. Kepuasan pelanggan dikonseptualisasikan sebagai perasaan yang timbul setelah mengevaluasi pengalaman pemakaian produk, Tjiptono dan Chandra (2005).

\section{METODE PENELITIAN}

Metode penelitian merupakan suatu teknik/cara untuk mencari, memperoleh, mengumpulkan, atau mencatat data, baik itu berupa data primer maupun data sekunder yang dapat digunakan untuk keperluan menyusun suatu penelitian dan kemudian menganalisis faktor faktor yang berhubungan dengan pokok pokok permasalahan sehingga akan didapat suatu kebenaran atas data yang diperoleh.

Metode ilmiah menurut Umi Narimawati (2008:127) menyatakan "Metode penelitian merupakan cara penelitian yang digunakan untuk mendapatkan data untuk mencapai tujuan tertentu." Sugiyono (2004:1) mendefinisikan "Metode penelitian pada dasarnya merupakan cara ilmiah untuk mendapatkan data dengan tujuan dan kegunaan tertentu." Metode yang digunakan dalam penelitian ini adalah metode Deskriptif dan Verifikatif. Menurut Sugiyono (2007:14) bahwa "Metode deskriptif analisis adalah statistik yang digunakan untuk menganalisa data dengan cara mendeskripsikan atau menggambarkan data yang telah terkumpul sebagaimana adanya." Sedangkan metode penelitian Verifikatif menurut Mashuri (2008:45), yaitu : Metode verifikatif yaitu memeriksa benar tidaknya apabila dijelaskan untuk menguji suatu cara dengan atau tanpa perbaikan yang telah dilaksanakan di tempat lain dengan mengatasi masalah yang serupa dengan kehidupan. Penelitian ini penulis memakai metode Deskriptif dengan pendekatan Kualitatif dan metode Verifikatif dengan pendekatan Kuantitatif yang di dapat dari dokumentasi.

Berdasarkan data yang diperoleh dari kepegawaian Setda Kabupaten Majalengka bahwa data pegawai sampai dengan pertengahan tahun 2020 sebanyak 276 . Teknik sampling pada penelitian ini menggunakan rumus slovin, maka jumlah sampel minimal yang bisa diambil berdasarkan rumus tersebut adalah sebanyak 164 pegawai yang bekerja di SETDA Kabupaten Bogor

Berdasarkan pada paradigma dan hipotesis penelitian yang telah disajikan pada bab sebelumnya, maka metode analisis data yang digunakan untuk menguji hipotesis adalah analisis jalur dengn variabel intervening dan variabel moderasi. Alasan penggunaan analisis jalur karena teknik 
analisis ini merupakan perluasan dari analisis regresi untuk mengestimasi hubungan kausalitas antar variabel yang telah ditetapkan sebelumnya berdasarkan teori. Berdasar analisis jalur dapat diketahui besarnya pengaruh langsung dan tidak langsung antara variabel, secara serempak atau bersama-sama dan parsial atau mandiri beberapa variabel penyebab terhadap sebuah variabel akibat. Dalam analisis jalur pengaruh independen dan dependen dapat berupa pengaruh langsung dan pengaruh tidak langsung (direct \& indirect effect), atau dengan kata lain analisis jalur memperhitungkan adanya pengaruh langsung dan tidak langsung. Pengaruh tidak langsung suatu independen variabel terhadap dependen variabel adalah melalui variabel yang lain yang disebut variabel antara (intervening variable). Sementara variabel moderator merupakan variabel yang turut mempengaruhi (baik memperlemah atau memperkuat) hubungan antara variabel independen ke dependen. Untuk menggambarkan hubunganhubungan kausalitas antar variabel yang akan diteliti pada penelitian ini digunakan diagram jalur (path diagram). Diagram jalur (path diagram) adalah alat untuk melukiskan secara grafis, struktur hubungan kausalitas antar variabel independen, intervening (intermediary), moderator dan variabel dependen.

Pengujian hipotesis dimaksudkan untuk mengetahui ada tidaknya pengaruh yang signifikan antara variabel independen kepada variabel dependen. Dalam pengujian hipotesis ini, peneliti menetapkan dengan menggunakan uji signifikan, dengan penetapan hipotesis nol (Ho) dan hipotesis alternatif (H1). Hipotesis nol (Ho) adalah suatu hipotesis yang menyatakan bahwa tidak ada pengaruh yang signifikan antara variabel independen dengan variabel dependen sedangkan hipotesis alternatif (Ha) adalah hipotesis yang menyatakan bahwa adanya pengaruh yang signifikan antara variabel independen dengan variabel dependen. Pengujian ini dilakukan secara simultan (uji F) maupun secara parsial (uji t)

\section{HASIL DAN PEMBAHASAN}

Hasil analisis koefisien korelasi antar variabel independen (peran manajerial kepala sekolah, budaya organisasi dan manajemen sarana prasarana) dapat dilihat pada tabel sebagai berikut :

Tabel 1. Koefisien Korelasi antar Variabel Independen

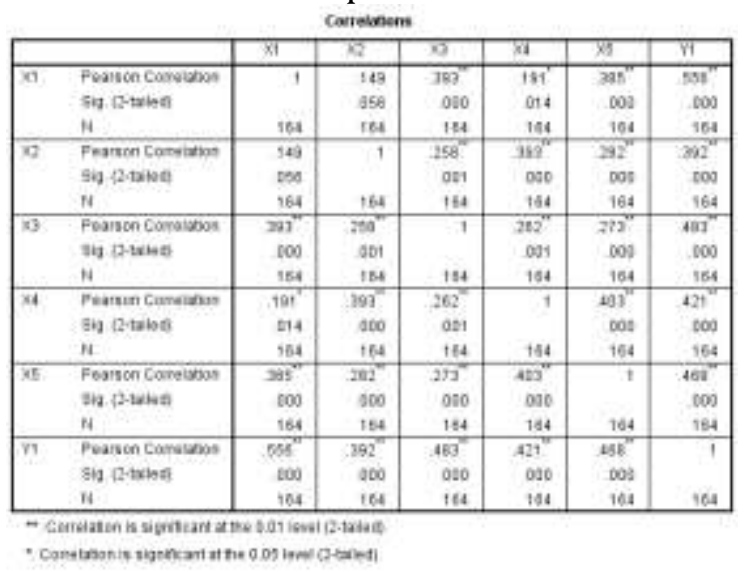

Berdasarkan tabel 1, dapat dianalisis koefisien korelasi sebagai berikut :

a) Nilai koefisien korelasi antara bukti fisik $\left(\mathrm{X}_{1}\right)$ dengan kehandalan $\left(\mathrm{X}_{2}\right)$ dengan nilai koefisien sebesar 0,149. Artinya, hubungan yang terjalin antara bukti fisik $\left(\mathrm{X}_{1}\right)$ dengan kehandalan $\left(\mathrm{X}_{2}\right)$ adalah sangat rendah.

b) Nilai koefisien korelasi antara bukti fisik $\left(\mathrm{X}_{1}\right)$ dengan daya tanggap $\left(\mathrm{X}_{3}\right)$ dengan nilai koefisien sebesar 0,393. Artinya, hubungan yang terjalin antara bukti fisik $\left(\mathrm{X}_{1}\right)$ dengan daya tanggap $\left(\mathrm{X}_{3}\right)$ adalah rendah.

c) Nilai koefisien korelasi antara bukti fisik (X1) dengan jaminan (X4) dengan nilai koefisien sebesar 0,191. Artinya, hubungan yang terjalin antara bukti fisik (X1) dengan jaminan (X4) adalah sangat rendah.

d) Nilai koefisien korelasi antara bukti fisik (X1) dengan empati (X5) dengan nilai koefisien sebesar 0,556. Artinya, hubungan yang terjalin antara bukti fisik (X1) dengan empati (X5) adalah cukup kuat.

e) Nilai koefisien korelasi antara kehandalan (X2) dengan daya tanggap (X3) dengan nilai koefisien sebesar 0,258. Artinya, hubungan yang terjalin antara kehandalan (X2) dengan daya tanggap (X3) adalah rendah.

f) Nilai koefisien korelasi antara kehandalan (X2) dengan jaminan (X4) dengan nilai koefisien sebesar 0,393. Artinya, hubungan yang terjalin antara 
kehandalan (X2) dengan jaminan (X4) adalah rendah.

g) Nilai koefisien korelasi antara kehandalan (X2) dengan jaminan (X4) dengan nilai koefisien sebesar 0,282. Artinya, hubungan yang terjalin antara kehandalan (X2) dengan jaminan (X4) adalah rendah.

h) Nilai koefisien korelasi antara jaminan (X4) dengan empati (X5) dengan nilai koefisien sebesar 0,403. Artinya, hubungan yang terjalin antara jaminan (X4) dengan empati (X5) adalah rendah.

i) Nilai koefisien korelasi antara daya tanggap (X3) dengan jaminan (X4) dengan nilai koefisien sebesar 0,262. Artinya, hubungan yang terjalin antara daya tanggap (X3) dengan jaminan (X4) adalah rendah.

j) Nilai koefisien korelasi antara daya tanggap $\left(\mathrm{X}_{3}\right)$ dengan empati $\left(\mathrm{X}_{5}\right)$ dengan nilai koefisien sebesar 0,273. Artinya, hubungan yang terjalin antara daya tanggap $\left(\mathrm{X}_{3}\right)$ dengan empati $\left(\mathrm{X}_{5}\right)$ adalah rendah.

Nilai koefisien korelasi antara daya tanggap $\left(\mathrm{X}_{3}\right)$ dengan empati $\left(\mathrm{X}_{5}\right)$ dengan nilai koefisien sebesar 0,273 . Artinya, hubungan yang terjalin antara daya tanggap $\left(\mathrm{X}_{3}\right)$ dengan empati $\left(\mathrm{X}_{5}\right)$ adalah rendah.

\section{PENUTUP}

Hasil penelitian terhadap kualitas pelayanan publik menunjukkan bahwa sebagian besar berada pada kategori cukup baik. Hal ini menunjukkan bahwa pelayanan public yang diberikan oleh Sekretaris Daerah Kabupaten Bogor telah ada upaya dalam memberikan pelayanan yang berkualitas, namun demikian masih ada indicator yang menjadi kelemahan dalam pelaksanaan pelayanan yang berkualitas di antaranya sikap dan karakter dalam memberikan pelayanan perlu dilakukan peningkatan agar dapat menghasilkan sumber daya manusia yang berkualitas.

Hasil penelitian terhadap kinerja organisasi menunjukkan bahwa sebagian besar berada pada kategori cukup baik. Hal ini menunjukkan bahwa kinerja organisasi yang telah diukur oleh instrument penelitian ini menunjukkan bahwa Sekretariat Daerah Kabupaten Bogor telah berupaya menunjukkan kinerja organisasi yang berkualitas, meskipun masih terdapat pelayanan yang dinilai perlu dilakukan peningkatan mengingat hasil penelitiannya menunjukkan indicator tersebut merupakan indicator terendah bila dibandingkan dengan indicator lainnya.

\section{DAFTAR PUSTAKA}

Agus Dwiyanto. 2008. Mewujudkan Good Governance melalui Pelayanan Publik. Yogyakarta : Gadjah Mada University Press.

Afrial, R. (2009) Kualitas Pelayanan Publik Kecamatan Sebuah Perubahan Kedudukan dan FungsiCamat Sebagai Perangkat Daerah. Jurnal Adminstrasi Dan Organisasi.

Albizar , Ferry. 2013. "Pengaruh Kualitas Layanan dan Kepercayaan Terhadap Kepuasan Nasabah Kredit Mikro Pada Bank", Jurnal Ilmiah Manajemen, No. 2, Vol. 14. Jurnal tidak diterbitkan.

As'ad, M. 1982. Seri Ilmu Sumber Daya Manusia, Psikologi Industri Edisi Revisi. Liberty. Yogyakarta.

Atep Adya Barata. (2003). Dasar- Dasar Pelayanan Prima. Jakarta : Elex Media. Kompetindo.

Dharma, S. (2005). Manajemen Kinerja. Jakarta: Pustaka Pelajar.

Duffy, K. G., \& Wong, F. Y. (2000). Community Psychology (2nd ed.). Boston: Pearson Education.

Dwight Waldo, Pengantar Studi Administrasi, Diterjemahkan oleh Slamet W. Admosoedarmo, Aksara Baru, jakarta, 2006.

Dwiyanto, Agus 1995. Penilaian Kinerja Organisasi Pelayanan Publik. Yogyakarta : Fisipol UGM.

Freddy Rangkuti. 2003. Teknik Mengukur dan Strategi Meningkatkan Kepuasan Konsumen. Jakarta: PT. Gramedia Pustaka.

H.A.S Moenir. 2014. Manajemen Pelayanan Umum Di Indonesia. Jakarta: Bumi Aksara.

Halim, Abdul dan M. Syam Kusufi. 2013. Akuntansi Sektor Publik: Akuntansi. Keuangan Daerah. Jakarta: Salemba Empat.

Hardiansyah.2011. Kualitas Pelayanan Publik. Yogyakarta: Gava Media.

Hasibuan, Malayu S.P. 2010. Manajemen 
Sumber Daya Manusia. Jakarta: PT Bumi. Aksara.

Henry Simamora. 2001. Manajemen Sumber Daya Manusia. STIE YKPN. Yogyakarta.

Ibrahim, Amin. 2008. Teori dan Konsep Pelayanan Publik Serta. Implementasinya. Jakarta: Mandar Maju.

Inu Kencana Syafiie, 2003. Sistem Pemerintahan Indonesia (Edisi Revisi), Rineka Cipta, ... Moekijat, Manajemen Kepegawaian, PT Bumi Aksara, Jakarta.

Khadafi, Muhammad. Nadirsyah. Abdullah, Syukriy. $2014 . \quad$ "pengaruh independensi, etika dan standar audit terhadap kualitas audit inspektorat Aceh". Jurnal akuntansi, Volume 3, No. 1, Februari 2014.

Lupiyoadi dan Hamdani, 2006. Manajemen Pemasaran jasa Edisi kedua. Penerbit Salemba Empat: Jakarta.

Manullang. (1985). Manajemen Personalia. Jakarta: Ghalia Indonesia.

Mardiasmo. 2009. Perpajakan, edisi revisi tahun 2009.Yogyakarta: Andi.

Mayer, R.C., Davis, J. H., dan Schoorman, F. D., (1995), An Integratif Model of Organizational Trust, Academy of Management Review, 30 (3): 709-734.

Menteri Pendayagunaan Aparatur Negara RI. Keputusan Menteri Pendayagunaan Aparatur Negara Nomor: 63/KEP/M.PAN/7/2003. Tentang Pedoman Umum Penyelenggaraan Pelayanan Publik..

Menteri Pendayagunaan Aparatur Negara RI. Keputusan Menteri Pendayagunaan Aparatur Negara Nomor: KEP/26/M.PAN/2/2004 tentang Petunjuk Teknis Transparansi dan Akuntabilitas dalam Penyelenggaraan Pelayanan Publik.

Moenir. 2000. Manajemen Pelayanan Publik. Jakarta: Bina Aksara.

Nawawi. 2011. Manajemen Sumber Daya Manuisa: Untuk Bisnis yang Kompetitif. Yogyakarta: Gajah Mada University Press.

Osborne, David, and Peter Plastrik. 1997. Banishing Bureaucracy, The Five Strategies For Reinventing Government, terjemahan : Memangkas
Birokrasi : Lima Strategi Menuju Pemerintahan Wirausaha, Alih Bahasa: Abdul Rosyid dan Ramelan. Jakarta : Penerbit PPM.

Osborne, David, and Ted Gaebler. 1992. Reinventing Government : How The Entrepreneur Spirit is Transforming The Public Service, terjemahan : Mewirausahakan Birokrasi Mentransformasikan Semangat Wirausaha ke Dalam Sektor Publik. Alih Bahasa Abdul Rosyid dan Ramelan. Jakarta : Pustaka Binaman Pressindo.

Pasolong, Harbani. 2010. Teori Administrasi Publik, Alfabeta, Bandung.

Ratminto, dan Atik Septi Winarsih. 2006. Manajemen Pelayanan. Jakarta : Pustaka Pelajar.

Samosir,, Z.Z. 2005. Pengaruh Kualitas Pelayanan Terhadap Kepuasan Mahasiswa Menggunakan Perpustakaan USU. Jurnal Studi Perpustakaan dan Informasi, Vol.1, No.1, Juni 2005.

Sinambela, Litjan Poltak, dkk. 2014. Reformasi Pelayanan Publik. Jakarta : PT Bumi Aksara.

Sinambela, Litjan Poltak, dkk. 2014. Reformasi Pelayanan Publik. Jakarta : PT Bumi Aksara.

Stoner, S., James A.F., Edward Freeman and Gilbert, Daniel. 2012. Management, New Jersey: Prentice Hall inc.

Supranto. (1997). Pengukuran tingkat kepuasan pelanggan untuk menaikkan pangsa pasar. Jakarta: Rineka Cipta.

Tjipto, F \& Diana A, 1996. Total Quality manajement, Yogyakarta, Andi Offset.

Tjiptono, Fandy dan Anastasia Diana. (2003). Total Quality Management. Edisi. Revisi. Yogyakarta: Andi Offset.

Tjiptono, Fandy dan G. Chandra. 2005. Service, Quality, \& Satisfaction. Yogyakarta: Penerbit Andi.

Undang Nomor 25 Tahun 2009 Tentang Pelayanan Publik.

Weigert, J. W. M. (1984). Social psychology, a sosiologycal approach through interpretative understanding. Indiana: University of Notre Dame Press.

Widodo, Joko. 2001. Good Governance: Telaah dari Dimensi: Akuntabilitas dan Kontrol Birokrasi pada Era 
Desentralisasi dan Otonomi Daerah.

Insan Cedekia. Surabaya.

Winardi. 2000, Kepemimpinan dalam

manajemen Jakarta, Rineka Cipta.

\section{BIOGRAFI PENULIS}

\begin{tabular}{||l|l||}
\hline & $\begin{array}{l}\text { Tiara Yulizar Puteri merupakan Mahasiswa Pascasarjana pada Program Studi Ilmu } \\
\text { Administrasi, di bawah bimbingan Dr. Otong Karyono, MT dengan penelitian yang } \\
\text { berjudul Analisis Hubungan Faktor-Faktor Kualitas Pelayanan dengan Kinerja } \\
\text { Pelayanan yang dilakukan pada Sekretaris Daerah Kabupaten Bogor. } \\
\text { Email: firstauthor@gmail.com }\end{array}$ \\
\hline
\end{tabular}

